\title{
In Vitro Cytotoxicity of Calcium Silicate-Based Endodontic Cement as Root-End Filling Materials
}

\author{
Selen Küçükkaya, ${ }^{1}$ Mehmet Ömer Görduysus, ${ }^{1,2}$ \\ Naciye Dilara Zeybek, ${ }^{3}$ and Sevda Fatma Müftüoğlu ${ }^{3}$ \\ ${ }^{1}$ Department of Endodontics, Faculty of Dentistry, Hacettepe University, 06100 Ankara, Turkey \\ ${ }^{2}$ Department of Endodontics, Dental College, University of Sharjah, Sharjah, UAE \\ ${ }^{3}$ Department of Histology and Embryology, Faculty of Medicine, Hacettepe University, 06100 Ankara, Turkey \\ Correspondence should be addressed to Selen Küçükkaya; selenkkkaya@yahoo.com
}

Received 7 December 2015; Revised 13 January 2016; Accepted 18 January 2016

Academic Editor: Peter Parashos

Copyright (C) 2016 Selen Küçükkaya et al. This is an open access article distributed under the Creative Commons Attribution License, which permits unrestricted use, distribution, and reproduction in any medium, provided the original work is properly cited.

\begin{abstract}
The aim of this study was to evaluate the cytotoxicity of three types of calcium silicate-based endodontic cement after different incubation periods with human periodontal ligament fibroblasts. Human periodontal ligament fibroblasts were cultured from extracted third molars and seeded in 96-well plates. MTA, calcium enriched mixture (CEM) cement, and Biodentine were prepared and added to culture insert plates which were immediately placed into 96-well plates containing cultured cells. After incubation periods of 24, 48, and 72 hours, cell viability was determined with WST-1 assay. Data were analysed statistically by ANOVA with repeated measures and Bonferroni tests. There was no significant difference in cell viability amongst the test materials after each incubation period $(P>0.05)$. MTA and CEM presented more than $90 \%$ cell viability after 24 and 48 hours of incubation and showed statistically significant decrease in cell viability after 72 hours of incubation $(P<0.05)$. Biodentine showed significantly less cell viability (73\%) after 24 hours of incubation, whereas more than $90 \%$ cell viability was seen after 48 and 72 hours of incubation $(P<0.05)$. Despite the significant changes in cell viability over time, materials presented similar cytotoxicity profile. Biodentine and CEM can be considered as alternative materials for root-end surgery procedures.
\end{abstract}

\section{Introduction}

Root-end surgery is a viable treatment option in the presence of persistent periradicular pathosis or when orthograde retreatment is considered unfeasible [1]. The ultimate success of the root-end surgery depends on the regeneration of a functional periodontal attachment apparatus, including cementum overlying the resected root-end surface, periodontal ligament (PDL), and alveolar bone [2]. To achieve this goal, it has been suggested to place a root-end filling material that not only prevents egress of any remaining bacteria or their by-products but also allows for the formation of a normal periodontium across its surface [3].

An ideal root-end filling material should be biocompatible, insoluble, dimensionally stable, radiopaque, antibacterial, and easy to manipulate and have effective sealing ability [4]. Because existing materials did not fulfill these characteristics, mineral trioxide aggregate (MTA), a calcium silicate-based material, was developed [5] and recommended for root-end filling because of its good physical and chemical properties [6]. MTA appears to be the most promising material to date, as it comes closest to being the ideal material for root-end filling. Nevertheless, MTA has some drawbacks such as a long setting time, difficult handling characteristics, and presence of toxic elements in the material composition [7]. Recently, new materials have been developed to be used for similar indications to MTA. Biodentine (Septodont, SaintMaur-des-Fosses, France), a more recent calcium silicate-based material, was introduced as a dentin substitute under resin composite restorations. Biodentine contains tricalcium silicate, calcium carbonate, and zirconium oxide and a water-based liquid-containing calcium chloride as the setting accelerator and a water-reducing agent [8]. Biodentine has been reported to exhibit short setting 
time and high mechanical properties [9]. Calcium enriched mixture (CEM cement, BioniqueDent, Tehran, Iran) is a recently introduced endodontic material which consists of several calcium compounds such as calcium silicate, calcium oxide, calcium phosphate, calcium carbonate, calcium sulfate, and calcium chloride [10]. It has been reported to have good handling characteristics, an ability to form hydroxyapatite in contact with tissue fluid [11], and superior antibacterial properties to that of MTA [12].

Biocompatibility is an important quality of root-end filling materials and cytotoxicity tests are primary biocompatibility tests which measures the capacity of a material to impact on cellular viability. Limited comparative data exist about the cytotoxicity of MTA, CEM, and Biodentine [13]. This study aimed to assess the cytotoxicity of MTA, CEM, and Biodentine on cultured human periodontal ligament fibroblasts using WST-1 (4-[3-(4-iodophenyl)-2-(4-nitrophenyl)2H-5-tetrazolio]-1,3-benzene disulfonate) assay.

\section{Materials and Methods}

2.1. Cell Culture Preparation. Following the university ethics committee approval (Ethics Board number GO-13/545), human periodontal tissue was obtained from extracted third molars of patients who had given their informed consent. The periodontal tissue was removed from the roots of the teeth and then divided into small pieces with sterile instruments. Periodontal tissue specimens were placed into $25 \mathrm{~cm}^{2}$ tissue culture flasks and were incubated with Dulbecco's modified Eagle medium (DMEM; Hyclone, Thermo Scientific, Logan, UT, USA) containing 10\% foetal bovine serum (FBS, Hyclone), 10000 units $/ \mathrm{mL}$ penicillin, $10 \mathrm{mg} / \mathrm{mL}$ streptomycin, and $200 \mathrm{mM}$ L-glutamine. The flasks were maintained at $37^{\circ} \mathrm{C}$ in a humidified incubator in an atmosphere of $5 \% \mathrm{CO}_{2}$. The medium was refreshed every 2 days. When outgrowth of cells was observed under phase contrast microscope (Figure 1(a)), the medium was replaced twice weekly until cells reached 75\% confluence (Figure 1(b)). The PDL fibroblasts from the fourth passage were used for the experiments. Prior to experimental tests, the cells were seeded at $1 \times 10^{4}$ cells/well in 96-well plates and $100 \mu \mathrm{L}$ medium was added to each well and incubated for 24 hours in an atmosphere of $5 \% \mathrm{CO}_{2}$ at $37^{\circ} \mathrm{C}$.

2.2. Preparation of Test Materials. The following materials were tested: White MTA Angelus (Angelus, Londrina, PR, Brazil), CEM (BioniqueDent, Tehran, Iran), and Biodentine (Septodont, Saint Maur des Fossés, France). Nine samples of each material were prepared according to the manufacturer's instructions and inserted into cylindrical polyethylene molds measuring $5 \mathrm{~mm}$ wide and $2 \mathrm{~mm}$ high (Figure $1(\mathrm{c})$ ). Samples were stored at $37^{\circ} \mathrm{C}$ in a chamber of $100 \%$ relative humidity before sterilization with ultraviolet rays for 24 hours. Thereafter, materials were added to culture insert plates (Millicell96 Cell Culture Insert Plate, PSHT004S5, Millipore, Darmstadt, Germany), which were immediately placed into 96-well plates containing the culture medium and cells (Figure $1(\mathrm{~d})$ ). Cells cultured with only culture insert plates without test materials served as controls. After incubation periods of 24, 48 , and 72 hours, each culture insert plate was removed and 96-well plates were used for cytotoxicity assay.

2.3. Cytotoxicity Assay. The Cell Proliferation Reagent WST-1 (Roche Diagnostics, Mannheim, Germany) was used to assess cell viability. This assay is based on the cleavage of a tetrazolium salt (WST-1) to soluble formazan dye by the mitochondrial dehydrogenase of living cells. At indicated time-points, $10 \mu \mathrm{L}$ of the WST- 1 reagent was added to each well, and the plates were incubated at $37^{\circ} \mathrm{C}$ for $4 \mathrm{~h}$. Subsequently, the optical densities of the plates were detected at $440 \mathrm{~nm}$ by micro-ELISA Reader (Versamax microplate reader, Molecular Devices). The percentage of relative cell viability was calculated using the following formula: (Test optical density/control optical density) $* 100$. All data were entered into the Statistical Package for the Social Sciences program (SPSS for Windows 11.0; SPSS Inc., Chicago, IL). All results were analysed statistically by ANOVA with repeated measures and Bonferroni tests.

\section{Results}

The cell viability of human PDL fibroblasts according to the groups is presented in Figure 2. There was no significant difference in cell viability between the test materials after 24, 48, and 72 hours of incubation $(P>0.05)$. However, significant changes were seen in cell viability over time for each material. MTA and CEM showed more than $90 \%$ cell viability after 24 and 48 hours of incubation, while they presented significantly less cell viability after 72 hours of incubation (60\% and 75\% cell viability, resp.) $(P<0.05)$. In contrast, Biodentine showed significantly less cell viability (73\% cell viability) after 24 hours of incubation, whereas more than $90 \%$ cell viability was seen after 48 and 72 hours of incubation $(P<0.05)$.

\section{Discussion}

There are several important issues to consider in the experimental design of in vitro cytotoxicity studies such as the choice of appropriate cell type, passage number, and assay type [3]. In this study, human PDL fibroblasts were used to simulate the clinical environment. The healing after root-end surgery includes the regrowth of PDL along the resected root surface [3]. Therefore, it is important to test how root-end filling materials affect the PDL fibroblasts. Cell lines with high passage numbers exhibit alterations in cell morphology [14]. In this study, we used fourth passage of cell lines which, being younger passages, presented minimal cell changes due to cell culture manipulation [14]. It has been proposed that cytotoxicity assay type should depend on the chemical composition of the test materials [3]. The tested materials in the present study are hydrophilic substances likely to release ionic components and interfere with intracellular enzyme activities. Thus, it is logical to choose an assay which measures mitochondrial dehydrogenase activity. The most widely used assay for this purpose is MTT assay and it is a first-generation tetrazolium derivative which is reduced in metabolically active cells by 


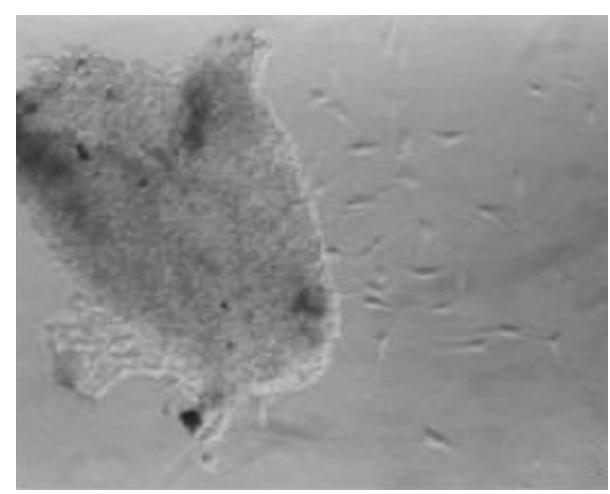

(a)

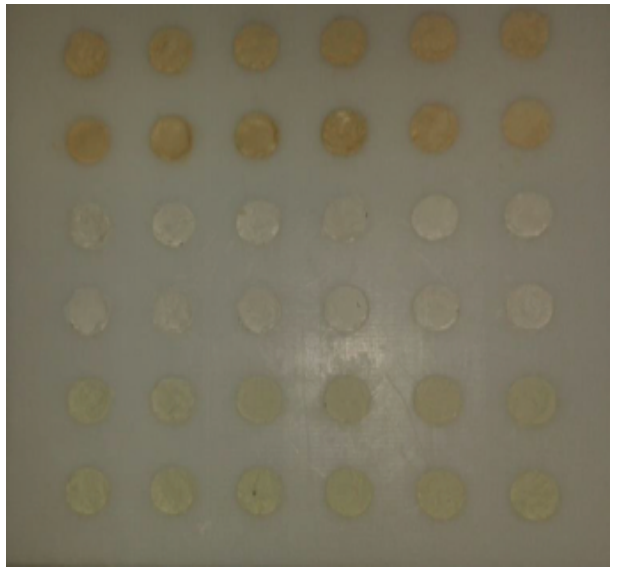

(c)

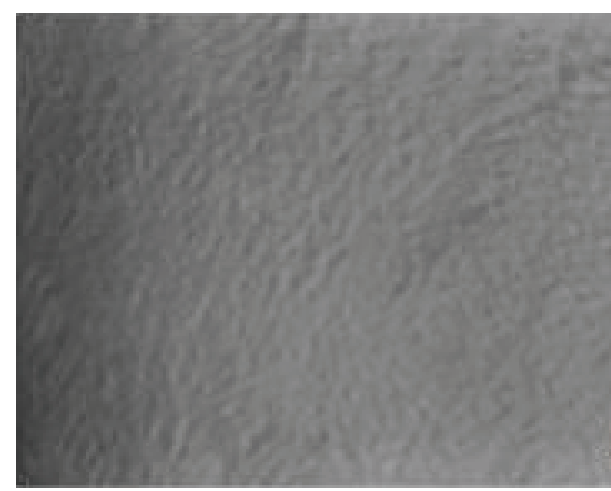

(b)

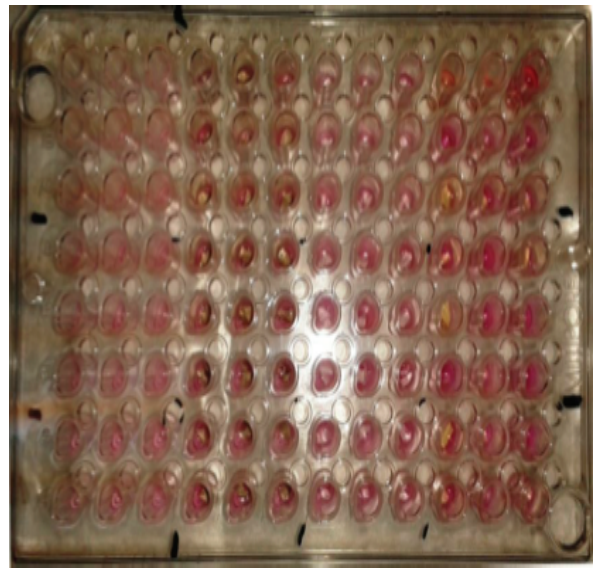

(d)

Figure 1: (a) Outgrowth of fibroblast cells from the tissue section $(\times 40$ magnification). (b) Fibroblast cells reached confluency $(\times 40$ magnification). (c) Materials inserted into cylindrical polyethylene molds. (d) The culture insert plate with materials placed into the 96-well plate.

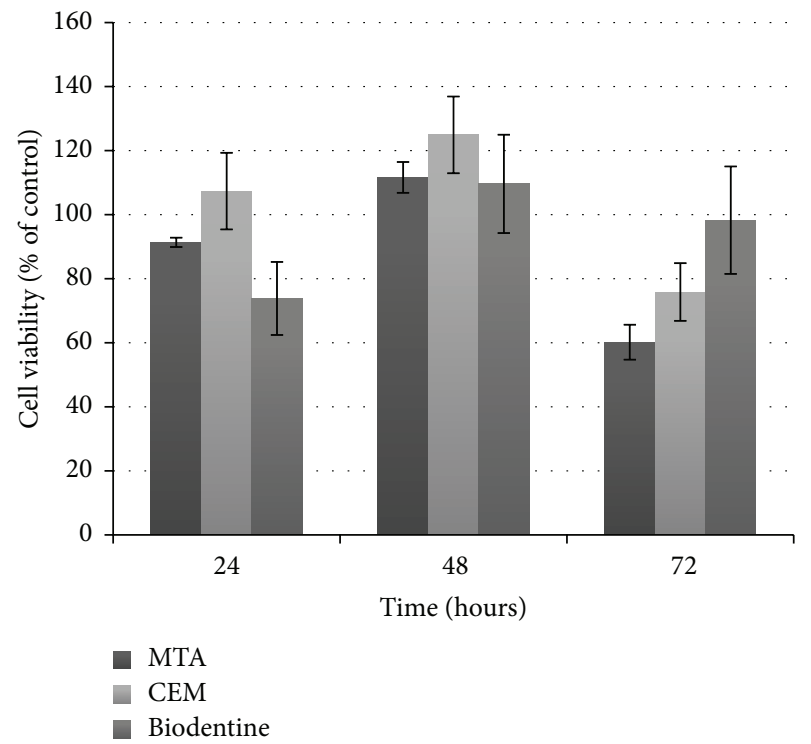

FIgURE 2: Cell viability of cultured human periodontal ligament fibroblasts after incubation with the tested materials for 24,48 , and 72 hours. Each bar represents the mean absorbance \pm standard deviation. a mitochondrial enzyme. However, MTT assay forms insoluble formazan crystals that requires the addition of a detergent and this step can complicate the assay [15]. WST-1 is a secondgeneration tetrazolium derivative which works similarly to MTT assay by reacting with the mitochondrial succinate tetrazolium reductase. WST-1 is metabolized into nontoxic, water-soluble, membrane-permeant products and does not require the solubilization step [15]. Therefore, WST-1 assay was used to determine the cell viability in the present study.

Adequate contact between cells and test material is also crucial to cell cytotoxicity testing. Contact between cells and material can be achieved in various ways [16]. Direct cellmaterial contact is a clinically relevant in vitro test model considering the exposure pattern between the root-end filling materials and periapical tissues. On the other hand, direct cell-material contact can influence cell viability through physical factors. It has been shown that the effect of direct contact between the cells and the material on testing may decrease the sensitivity of an in vitro system [17]. Besides, the particulate and solid nature of the test materials may interfere with reading in the optical reader when the materials are placed in direct contact with cells. At this point using material extracts could be a viable solution to assess the cytotoxicity 
indirectly. However, it would be less clinically relevant considering the limited solubility capacity of the test materials and their ability to release different molecules through time due to their setting reactions and interaction with the cells [18]. To bypass these problems, we used culture insert plates to carry the test materials through incubation periods. Cells come into close proximity to the test materials while soluble compounds from the materials reach the cells through the pores of culture insert plates [17]. Therefore, using culture insert plates allowed repeated and consecutive exposure of the same cells over an extended time.

In the present study, no significant difference was detected between MTA, CEM, and Biodentine for each incubation period. These results are in agreement with those found in previous cytotoxicity studies [19-23]. However, cell viability showed significant differences over time for all materials. MTA and CEM showed a statistically significant decrease in cell viability after 72 hours of incubation whereas Biodentine showed less cell viability after 24 hours of incubation compared with other time periods. The reason for the decrease in cell viability for MTA and CEM after 72 hours of incubation may be the production of calcium hydroxide due to the hydration reaction in the materials $[10,24]$. Similarly, calcium hydroxide is produced as a by-product of the reaction in Biodentine [25]. However, the liquid for mixing with the Biodentine powder consists of calcium chloride which results in accelerated cement by decreasing the setting time [25]. Early production of calcium hydroxide can explain why Biodentine showed relatively less cell viability after 24 hours of incubation rather than other time periods [26]. It is also important to consider the clinical significance of this issue. The gradual release of hydroxyl ions may decrease cell viability in vitro. However, under in vivo conditions high alkalinity due to hydroxyl ions may be neutralized by the body tissue fluid and may not cause significant effects on cell viability [20].

Degradation products and elution substances from materials can induce cytotoxicity [27]. In this regard, there have been some concerns about the purity of MTA since it is based on a clinker related to Portland cement. According to recent studies, MTA showed evidence of heavy metals such as arsenic, chromium, and lead and the presence of aluminate phase which have been associated with toxicity $[28,29]$. Biodentine is claimed by the manufacturer as a high purity dental material due to its production with Active Biosilicate Technology. However, a recent study has found traces of arsenic, chromium, and lead in elutes from a mixed Biodentine solution but also verified that aluminate phase is not included in Biodentine [30]. The biocompatibility of radiopacifiers in materials can be another important issue since they have been observed in high levels in tissues adjacent to the material [31]. MTA has bismuth oxide as a radiopacifier [6]. Several studies demonstrated that the addition of bismuth oxide to Portland cement showed higher cytotoxicity compared with Portland cement alone [32, 33]. On the other hand, Biodentine contains zirconium oxide as a radiopacifier which presents a lower toxicity profile than bismuth oxide [27, 34]. These properties may have contributed to the results of Biodentine which demonstrated relatively high cell viability at all time periods in the present study.

Laboratory studies cannot simulate the complex biological conditions of the clinical status. Therefore, the results obtained from the preliminary cytotoxicity tests have limitations with respect to direct correlation with clinical situations. However, they do provide reproducible and reliable means for comparing and testing new materials and establishing international standards. According to the results of the present in vitro study all materials showed changes in cell viability over time; however, there was no difference between materials in terms of cytotoxicity and each material presented acceptable cell viability as being consistent with a limited number of in vivo studies in the literature [35-37].

In conclusion, CEM and Biodentine presented similar cytotoxicity profiles to MTA and can be considered as alternative materials for root-end surgery procedures.

\section{Conflict of Interests}

The authors declare that there is no conflict of interests regarding the publication of this paper.

\section{Acknowledgment}

This study was supported and granted by the Hacettepe University Scientific Research Fund, Project no. 013D11201002.

\section{References}

[1] J. L. Gutmann and J. W. Harrison, "Posterior endodontic surgery: anatomical considerations and clinical techniques," International Endodontic Journal, vol. 18, no. 1, pp. 8-34, 1985.

[2] J. O. Andreasen and J. Rud, "Modes of healing histologically after endodontic surgery in 70 cases," International Journal of Oral Surgery, vol. 1, no. 3, pp. 148-160, 1972.

[3] K. Keiser, C. C. Johnson, and D. A. Tipton, "Cytotoxicity of mineral trioxide aggregate using human periodontal ligament fibroblasts," Journal of Endodontics, vol. 26, no. 5, pp. 288-291, 2000.

[4] B. S. Chong and T. R. Pitt Ford, "Root-end filling materials: rationale and tissue response," Endodontic Topics, vol. 11, no. 1, pp. 114-130, 2005.

[5] M. Torabinejad, T. F. Watson, and T. R. Pitt Ford, "Sealing ability of a mineral trioxide aggregate when used as a root end filling material," Journal of Endodontics, vol. 19, no. 12, pp. 591-595, 1993.

[6] M. Torabinejad, C. U. Hong, F. McDonald, and T. R. Pitt Ford, "Physical and chemical properties of a new root-end filling material," Journal of Endodontics, vol. 21, no. 7, pp. 349-353, 1995.

[7] M. Parirokh and M. Torabinejad, "Mineral trioxide aggregate: a comprehensive literature review-part III: clinical applications, drawbacks, and mechanism of action," Journal of Endodontics, vol. 36, no. 3, pp. 400-413, 2010.

[8] P. Laurent, J. Camps, M. De Méo, J. Déjou, and I. About, "Induction of specific cell responses to a $\mathrm{Ca}_{3} \mathrm{SiO}_{5}$-based posterior restorative material," Dental Materials, vol. 24, no. 11, pp. 14861494, 2008. 
[9] L. Grech, B. Mallia, and J. Camilleri, "Investigation of the physical properties of tricalcium silicate cement-based root-end filling materials," Dental Materials, vol. 29, no. 2, pp. e20-e28, 2013.

[10] S. Asgary, S. Shahabi, T. Jafarzadeh, S. Amini, and S. Kheirieh, "The properties of a new endodontic material," Journal of Endodontics, vol. 34, no. 8, pp. 990-993, 2008.

[11] S. Asgary, M. J. Eghbal, M. Parirokh, and J. Ghoddusi, "Effect of two storage solutions on surface topography of two root-end fillings," Australian Endodontic Journal, vol. 35, no. 3, pp. 147$152,2009$.

[12] S. Asgary, F. Akbari Kamrani, and S. Taheri, "Evaluation of antimicrobial effect of MTA, calcium hydroxide, and CEM cement," Iranian Endodontic Journal, vol. 2, no. 3, pp. 105-109, 2007.

[13] S. Khedmat, S. Dehghan, J. Hadjati, F. Masoumi, M. H. Nekoofar, and P. M. H. Dummer, "In vitro cytotoxicity of four calcium silicate-based endodontic cements on human monocytes, a colorimetric MTT assay," Restorative Dentistry \& Endodontics, vol. 39, no. 3, pp. 149-154, 2014.

[14] C. K. Karimjee, S. Koka, D. M. Rallis, and T. G. Gound, "Cellular toxicity of mineral trioxide aggregate mixed with an alternative delivery vehicle," Oral Surgery, Oral Medicine, Oral Pathology, Oral Radiology and Endodontology, vol. 102, no. 4, pp. el15-e120, 2006.

[15] R. J. Kim and J. H. Shin, "Cytotoxicity of a novel mineral trioxide aggregate-based root canal sealer," Dental Materials Journal, vol. 33, no. 3, pp. 313-318, 2014.

[16] G. L. Polyzois, "In vitro evaluation of dental materials," Clinical Materials, vol. 16, no. 1, pp. 21-60, 1994.

[17] A. T. H. Tang, J. Li, J. Ekstrand, and Y. Liu, "Cytotoxicity tests of in situ polymerized resins: methodological comparisons and introduction of a tissue culture insert as a testing device," Journal of Biomedical Materials Research, vol. 45, no. 3, pp. 214222, 1999.

[18] C. Prati and M. G. Gandolfi, "Calcium silicate bioactive cements: biological perspectives and clinical applications," Dental Materials, vol. 31, no. 4, pp. 351-370, 2015.

[19] H.-M. Zhou, Y. Shen, Z.-J. Wang et al., "In vitro cytotoxicity evaluation of a novel root repair material," Journal of Endodontics, vol. 39, no. 4, pp. 478-483, 2013.

[20] M. A. Mozayeni, A. S. Milani, L. A. Marvasti, and S. Asgary, "Cytotoxicity of calcium enriched mixture cement compared with mineral trioxide aggregate and intermediate restorative material," Australian Endodontic Journal, vol. 38, no. 2, pp. 7075, 2012.

[21] G. N. Attik, C. Villat, F. Hallay et al., "In vitro biocompatibility of a dentine substitute cement on human MG63 osteoblasts cells: Biodentine versus MTA ${ }^{\circledR}$," International Endodontic Journal, vol. 47, no. 12, pp. 1133-1141, 2014.

[22] C. M. Corral Nuñez, H. J. Bosomworth, C. Field, J. M. Whitworth, and R. A. Valentine, "Biodentine and mineral trioxide aggregate induce similar cellular responses in a fibroblast cell line," Journal of Endodontics, vol. 40, no. 3, pp. 406-411, 2014.

[23] N. Naghavi, J. Ghoddusi, H. R. Sadeghnia, E. Asadpour, and S. Asgary, "Genotoxicity and cytotoxicity of mineral trioxide aggregate and calcium enriched mixture cements on L929 mouse fibroblast cells," Dental Materials Journal, vol. 33, no. 1, pp. 64-69, 2014.

[24] J. Camilleri and T. R. Pitt Ford, "Mineral trioxide aggregate: a review of the constituents and biological properties of the material," International Endodontic Journal, vol. 39, no. 10, pp. 747-754, 2006.

[25] J. Camilleri, F. Sorrentino, and D. Damidot, "Investigation of the hydration and bioactivity of radiopacified tricalcium silicate cement, Biodentine and MTA Angelus," Dental Materials, vol. 29, no. 5, pp. 580-593, 2013.

[26] J. R. Kim, A. Nosrat, and A. F. Fouad, "Interfacial characteristics of Biodentine and MTA with dentine in simulated body fluid," Journal of Dentistry, vol. 43, no. 2, pp. 241-247, 2015.

[27] A. L. Gomes Cornélio, L. P. Salles, M. Campos Da Paz, J. A. Cirelli, J. M. Guerreiro-Tanomaru, and M. Tanomaru Filho, "Cytotoxicity of Portland cement with different radiopacifying agents: a cell death study," Journal of Endodontics, vol. 37, no. 2, pp. 203-210, 2011.

[28] M. Schembri, G. Peplow, and J. Camilleri, "Analyses of heavy metals in mineral trioxide aggregate and Portland cement," Journal of Endodontics, vol. 36, no. 7, pp. 1210-1215, 2010.

[29] C. Monteiro Bramante, A. C. C. O. Demarchi, I. G. de Moraes et al., "Presence of arsenic in different types of MTA and white and gray Portland cement," Oral Surgery, Oral Medicine, Oral Pathology, Oral Radiology and Endodontology, vol. 106, no. 6, pp. 909-913, 2008.

[30] J. Camilleri, P. Kralj, M. Veber, and E. Sinagra, "Characterization and analyses of acid-extractable and leached trace elements in dental cements," International Endodontic Journal, vol. 45, no. 8, pp. 737-743, 2012.

[31] M. D. Lazarus, J. M. Cuckler, H. R. Schumacher Jr., P. Ducheyne, and D. G. Baker, "Comparison of the inflammatory response to particulate polymethylmethacrylate debris with and without barium sulfate," Journal of Orthopaedic Research, vol. 12, no. 4, pp. 532-541, 1994.

[32] K.-S. Min, H.-S. Chang, J.-M. Bae, S.-H. Park, C.-U. Hong, and E.-C. Kim, "The induction of heme oxygenase-1 modulates bismuth oxide-induced cytotoxicity in human dental pulp cells," Journal of Endodontics, vol. 33, no. 11, pp. 1342-1346, 2007.

[33] E.-C. Kim, B.-C. Lee, H.-S. Chang, W. Lee, C.-U. Hong, and K.-S. Min, "Evaluation of the radiopacity and cytotoxicity of Portland cements containing bismuth oxide," Oral Surgery, Oral Medicine, Oral Pathology, Oral Radiology and Endodontology, vol. 105, no. 1, pp. e54-e57, 2008.

[34] G. F. Silva, R. Bosso, R. V. Ferino et al., "Microparticulated and nanoparticulated zirconium oxide added to calcium silicate cement: evaluation of physicochemical and biological properties," Journal of Biomedical Materials Research Part A, vol. 102, no. 12, pp. 4336-4345, 2014.

[35] A. Nosrat, A. Seifi, and S. Asgary, "Pulpotomy in caries-exposed immature permanent molars using calcium-enriched mixture cement or mineral trioxide aggregate: a randomized clinical trial," International Journal of Paediatric Dentistry, vol. 23, no. 1, pp. 56-63, 2013.

[36] S. Asgary, M. J. Eghbal, and S. Ehsani, "Periradicular regeneration after endodontic surgery with calcium-enriched mixture cement in dogs," Journal of Endodontics, vol. 36, no. 5, pp. 837$841,2010$.

[37] A. Nowicka, M. Lipski, M. Parafiniuk et al., "Response of human dental pulp capped with biodentine and mineral trioxide aggregate," Journal of Endodontics, vol. 39, no. 6, pp. 743-747, 2013. 


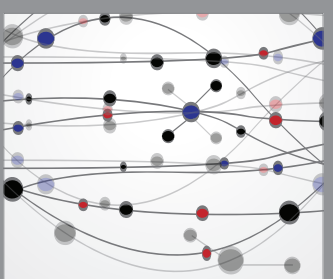

The Scientific World Journal
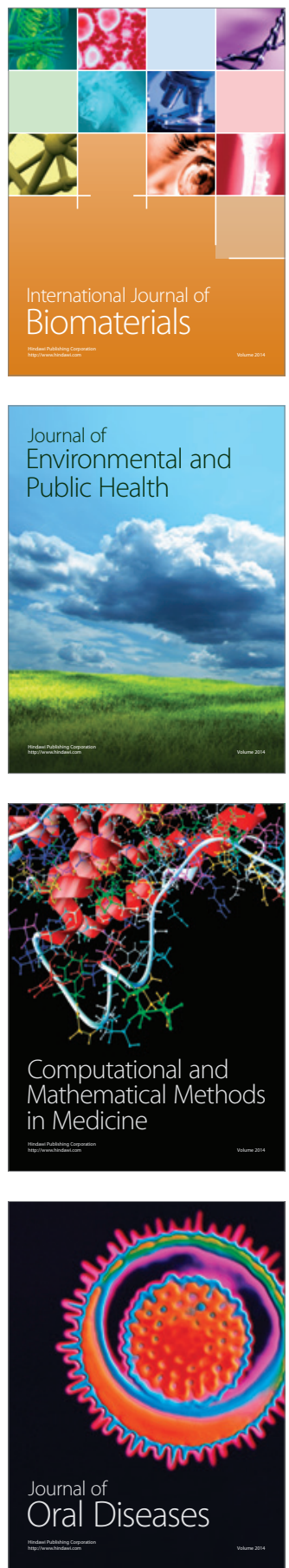
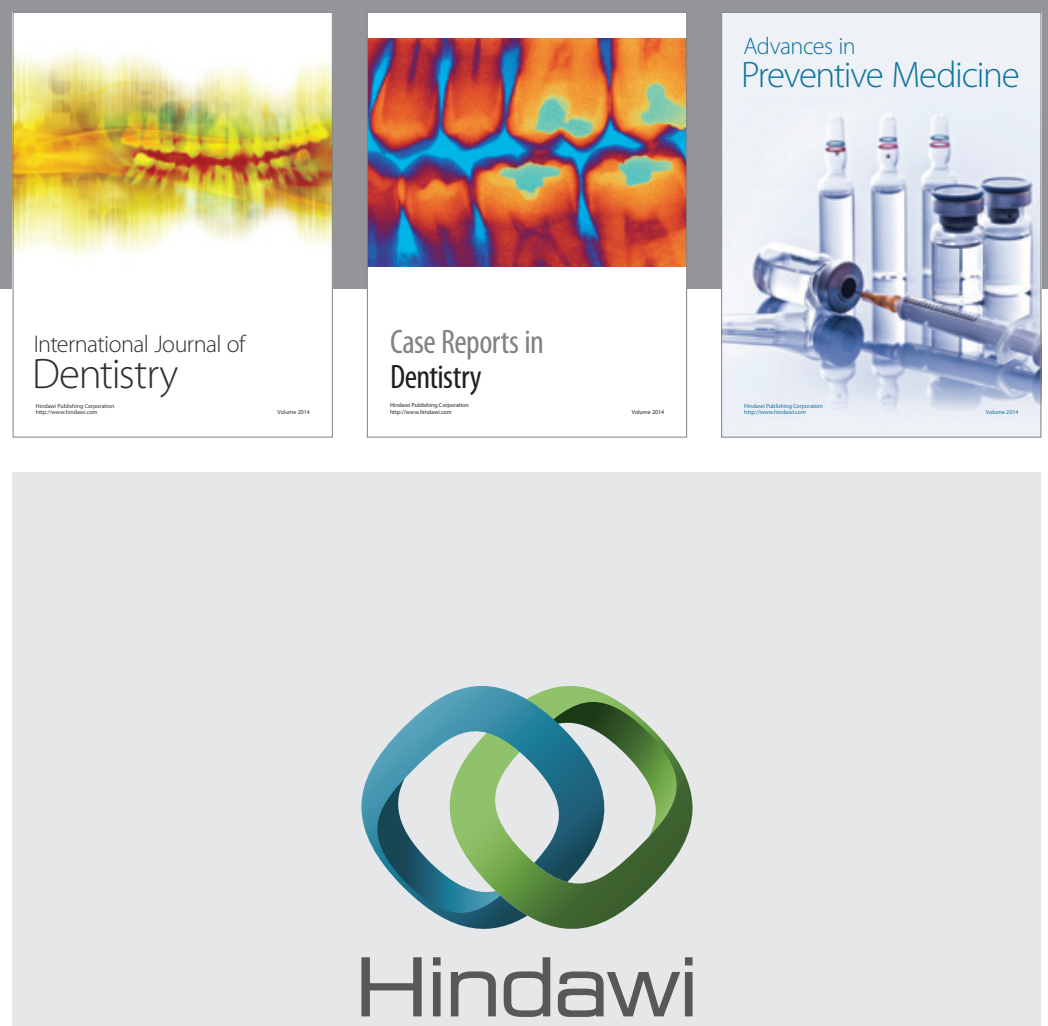

Submit your manuscripts at

http://www.hindawi.com
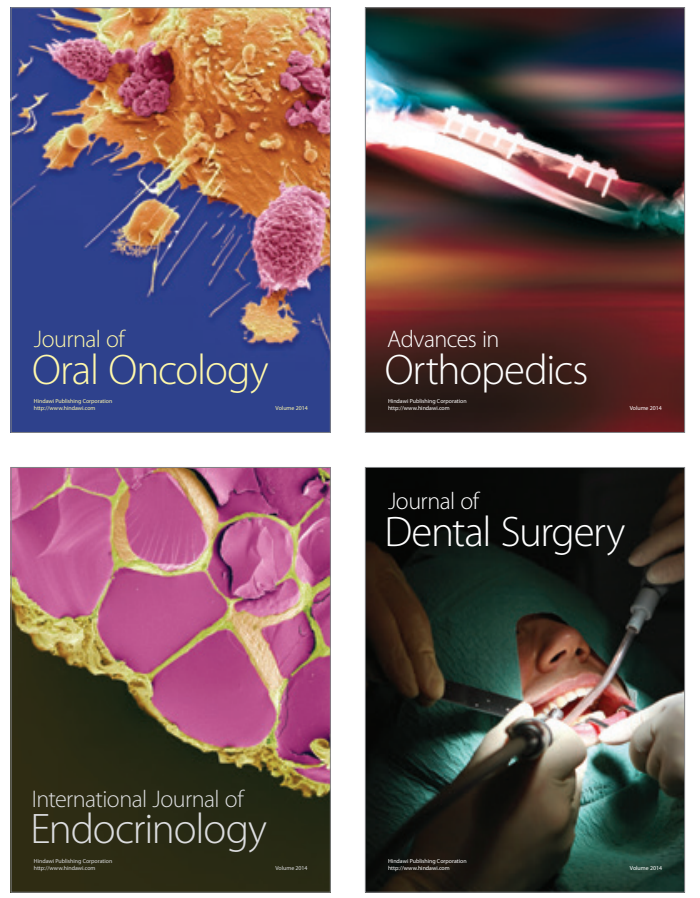
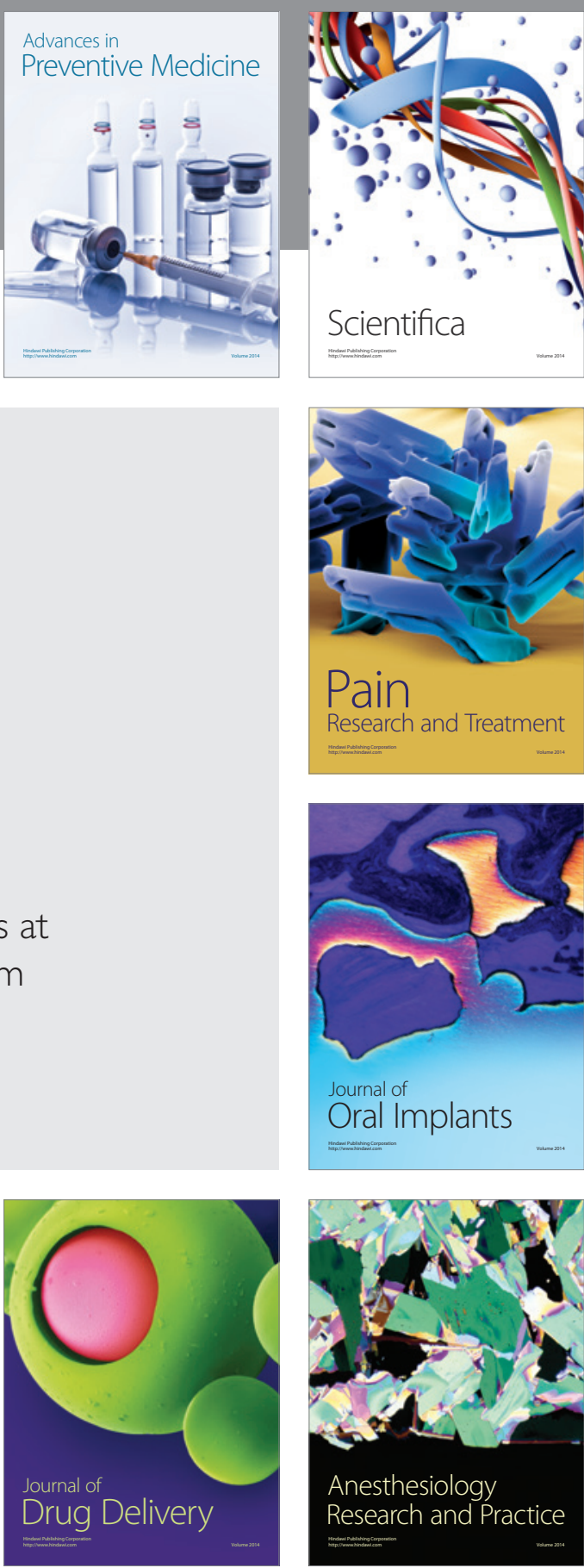

Scientifica
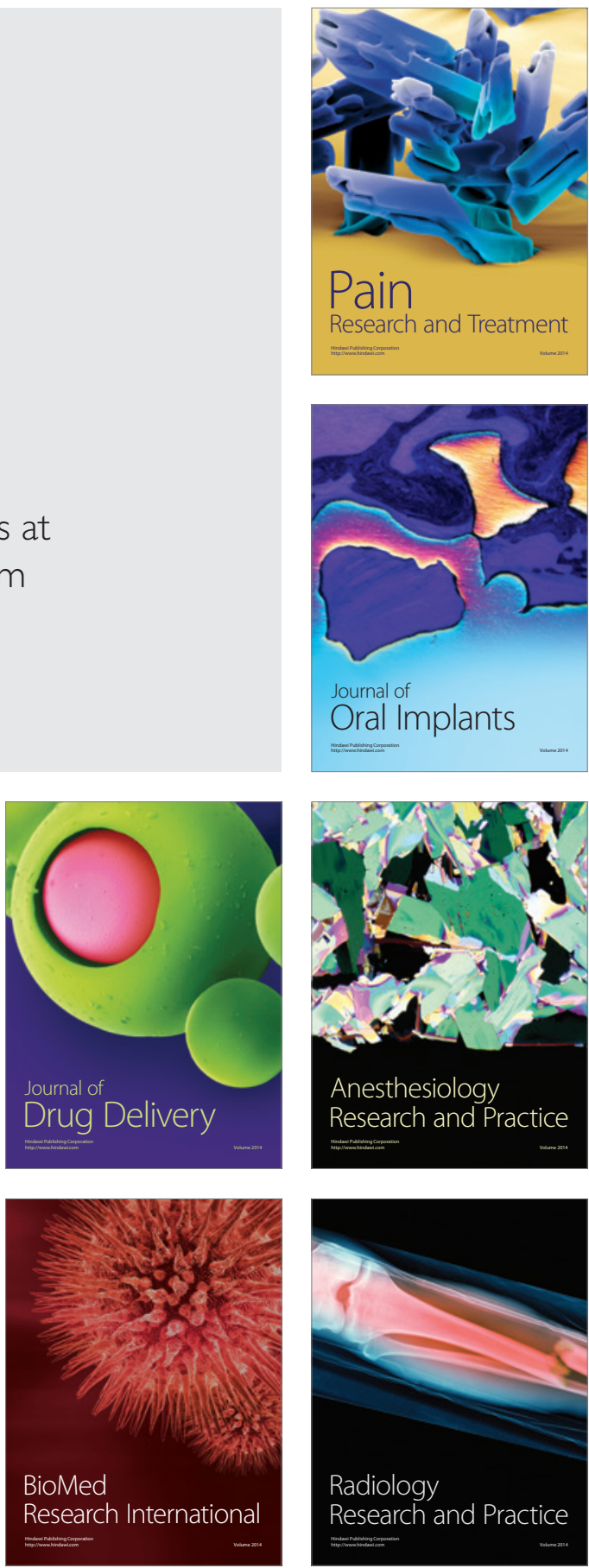